\title{
Choosing one's future? Narratives on educational and occupational choice among folk high school participants in Sweden
}

\author{
Andreas Fejes $^{1}$ D $\cdot$ Magnus Dahlstedt ${ }^{2}$
}

Received: 24 October 2018 / Accepted: 9 March 2019 / Published online: 27 March 2019

(c) The Author(s) 2019

\begin{abstract}
This article poses these questions: How do participants on two different courses in folk high schools in Sweden, a basic course and a theatre course, motivate their educational and occupational choices, and what similarities and differences can be identified? We analyse interviews with students drawing on a narrative approach. Five trajectories emerge: desire to get away; desire to get back on track; desire for employment; desire to change occupation; and desire to realise one's dreams. We argue that these trajectories reproduce existing social stratification in society, whereby certain futures are available to some people, and not to others.
\end{abstract}

Keywords Educational and occupational choice $\cdot$ Narrative analysis $\cdot$ Folk high schools

\section{Résumé}

Choisir son future ? Narratives sur le choix éducationnel et occupationnel chez des lycéens en Suède. Cet article pose deux questions : Comment est-ce que les participants à deux cours différents de lycées en Suède, un cours basique et un cours de théâtre, motivent leur choix éducationnels et occupationnels, et quelles similarités et différences peuvent être identifiées ? Nous analysons les entretiens avec les étudiants en nous basant sur une approche narrative. Cinq trajectoires apparaissent : le désir de partir; le désir de se remettre sur les rails; le désir d'un emploi; le désir de changer d'occupation; et le désir de réaliser ses rêves. Nous soutenons que ces trajectoires reproduisent une stratification sociale existante dans la société, dans laquelle certains futurs sont disponibles pour certaines personnes, et pas pour d'autres.

\section{Zusammenfasung}

Die Zukunft wählen? Erzählungen über die Ausbildungs- und Berufswahl Schwedischer Volkshochschüler/innen. Dieser Artikel stellt folgende Fragen: Welches sind die Beweggründe der Teilnehmer/innen zweier unterschiedlicher Volkshochschulkurse in Schweden, eines Grundkurses und eines Theaterkurses, zur Wahl

Extended author information available on the last page of the article 
ihrer Ausbildungs- und Berufswege, welche Ähnlichkeiten und Unterschiede können identifiziert werden? Wir analysieren Interviews mit Studierenden, gestützt auf einen narrativen Ansatz. Es resultieren fünf Kategorien: Der Wunsch, wegzukommen; der Wunsch, wieder auf den richtigen Weg zu kommen; der Wunsch nach einer Anstellung; der Wunsch nach einem Berufswechsel und der Wunsch, seine Träume zu verwirklichen. Wir behaupten, dass diese Trajektorien bestehende soziale Schichtungen der Gesellschaft widerspiegeln, wobei bestimmte Optionen für einige Menschen verfügbar sind, für andere jedoch nicht.

\section{Resumen}

Escogiendo el propio futuro? Narrativas sobre la elección educativa y ocupacional entre jóvenes de secundaria postobligatoria en Suecia. Este artículo plantea estas cuestiones: ¿Como motivan sus elecciones académicas y profesionales los jóvenes participantes un curso básico y uno de teatro en los centros de educación secundaria superior en Suecia? Y ¿qué similitudes y diferencias pueden identificarse? Se analizan entrevistas con los estudiantes que dibujan su aproximación narrativa. Emergen cinco trayectorias: el deseo de marchar, el deseo de volver al itinerario, el deseo de empleo, el deseo de cambio de ocupación y el deseo de realizar los propios sueños. Se argumenta que estas trayectorias reporducen la estratificación social existente en la cual algunos futuros están disponibles para algunas personas y no para otras.

\section{Introduction}

This article focuses on occupational choice as a component of students' life histories, embedded in specific social structures and contexts (Reay, 1995; Reay, David $\&$ Ball, 2005). The article is a response to the argument that there is a need for greater focus on the life histories of individuals, and how these are connected to wider social structures, in order to understand how and why occupational choices are made (cf. Hodkinson \& Sparkes, 1997; Bloomer \& Hodkinson, 2000; Billett, Newton \& Ockerby, 2010). We specifically focus on an educational institution in Sweden, the folk high school (FHS), that primarily delivers non-formal education, ranging from compensatory education to elite education. More specifically, we are interested in the reasons why participants choose to study the courses they do and what their occupational aspirations are.

There is an extensive body of literature on occupational choice and career aspirations. This literature has shown that occupational choices are based on both intrinsic and extrinsic factors (Fejes \& Nicoll, 2010). Here, calls have been made for a situational understanding, focusing on how occupational choices are actually made, and what motivates individuals to choose certain careers (Billett et al. 2010). Occupational choices have been explained in different ways: in terms of rational decision-making (for an overview, see Billett et al. 2010), social structures and processes (Simpson, 2005; Gottfredson \& Lapan, 1997), and personal values and life histories (Billett et al. 2010; Fejes \& Köpsén, 2014). 
In societies characterised by increasing individualisation, occupational choice may appear to be neutral, as though both success and failure in terms of careers should be ascribed solely to the capacities (or lack thereof) of the individual (Evans, 2002). However, career aspirations are related to a range of interconnected factors, such as gender, socioeconomic status, race, occupational and educational levels in the family, and expectations of parents (Rojewski \& Yang, 1997; Lidström, 2010). Individuals from families with higher socioeconomic status are generally more likely to have knowledge about and also to actively choose professional occupations, while the career aspirations of individuals from low-income families tend to be more tied to the experiences of their relatives and friends (see e.g. Brown \& Barbosa, 2001; Sellers, Satcher \& Comas 1999; Mau \& Bikos 2000).

Similar tendencies have been identified in a Swedish context as pertaining to, amongst others, municipal adult education (MAE) (Fejes et al., 2018) and FHS. Previous research has illustrated, for example, that participants engaging in FHS courses in the cultural area, to a greater extent than participants on the basic course, come from families with a higher educational background (Fürst, Levelius \& Nylander, 2018). In a similar line, Rubenson (1975) showed, in the 1970s, how participants in adult education with previous higher levels of education, were more likely to choose adult education as means for personal development of for getting better at their job, as compared to those with lower levels of education. In the 2000s, Assarsson and Sipos Zackrisson (2005, 2006), identified five main reasons for why adults engaged in adult education during the adult education initiative 1997-2002, when the Swedish state made the largest investment in adult education ever. These reasons were: education as means for self realisation; supporting oneself (financially through student loan); socialising; qualifications; and learning. In sum, these studies illustrate a range of reasons for engaging in studies in adult education (including FHS).

In order to further enquire into the ways in which educational and occupational choices are made by participants enrolled in FHS, this article focus on the participants' life stories, asking the question: How do participants on different courses at FHS motivate their educational and occupational choices in relation to their specific life histories? What similarities and differences can be identified among participants on these two courses?

\section{Folk high schools in Sweden}

FHS in Sweden provide an interesting case for further elaboration in terms of adult students' educational and occupational choice. On the one hand, FHS provide courses ranging from elite education to courses for those with short education who wishes to complete their compulsory school education. Thus, the student population is varied, so are the reasons for entering FHS. On the other hand, FHS is a unique education institution, with few equivalents across the world.

Sweden has a long history of institutionalised popular education, dating back to the mid-1800s, with the emergence of the first FHS (in 1868), study circles (the first created in 1902), public libraries, distance education, public lectures and the creation of the first study association in 1912. These institutions were developed in 
close cooperation between social movements and the state (Gustavsson, 2013; Larsson, 2013). This close relationship has lasted throughout the 20th and into the 21st century, and was part of the corporatist arrangement of the Swedish welfare model (Micheletti, 1995; Premfors, 2000). In this model, relations between the state and civil society organisations were seen as important for the development a more democratic society. The idea was that decisions would be more embedded in the broad layers of the population and that high levels of participation in the activities of such organisations would contribute to the fostering of a democratic population (Edquist, 2009). Thus, popular education in Sweden is quite different from that in other countries, where the relationship between popular educational institutions and the state looks different, where popular education is organised as independent from-or even in opposition to-the state (Kane, 2013).

The FHS were originally created by the rich landowning farmers as a way for their sons to learn their trade. These schools were the first in Sweden to make education beyond primary level possible. FHS quickly became popular and by the year 1900 there were 29 FHS in Sweden. These schools were mainly located in the countryside, where educational opportunities were scarce (Larsson, 2013). With the social movements of the early 1900s, FHS were developed into schools for the movement's functionaries-many of whom were working class. In the 1930s, the majority of participants came from the working class, and there was a majority of female participants. Thus, these schools came to serve as the only possibility for further schooling of the working class at that time (Larsson, 2013).

Today, FHS in Sweden have two kinds of owners: regional (county) councils and non-governmental organisations. In 2018 there were 155 FHS, spread across the country. Historically, many FHS were set up as boarding schools, although, since the 1990s, many have re-organised themselves as daytime schools, without accommodation. State funding is provided for two kinds of courses: short and long. The former could be courses lasting only a few days, while the latter range from 15 days to several semesters. Long courses are also divided between those providing eligibility for higher education (the basic course), and specialised courses, including vocational courses, e.g. the youth recreational programme, as well as cultural courses, which could be vocational, e.g. music or theatre courses.

The number of participants enrolled onto long courses in the autumn of 2017 was 32,550 (13,360 on basic and 19,190 on specialised courses), while the number of participants on the short courses was 38,140 (Swedish Council for Adult Education, 2018). As FHS offer a range of courses, participants have quite diverse backgrounds. Those who enrol onto the basic course are people who might have failed compulsory and/or upper secondary schooling. These participants often have a workingclass background, and a relatively high proportion of participants on these courses have a migrant background (41\%). Participants on the specialised courses are quite diverse, depending on which of the courses they attend. But participants with a migrant background only make up $15 \%$ of the people on these courses.

If one focuses on the cultural courses only (one branch of the specialised courses), a large proportion of participants have a middle-class background (in terms of parents' educational attainment), and very few have a migrant background. This is especially true of cultural courses in the areas of music, writing and theatre, where only 
$11 \%$ of the participants have a migrant background (Fürst et al. 2018). Some of these cultural courses could be seen as elite education. For instance, as Nylander (2014) points out, jazz education at FHS is a course that participants must attend in order to gain access to the jazz music elite in Sweden. Studying this particular course at the two most prestigious FHS delivering these courses is even more prestigious than studying at the national music conservatory. Thus, FHS are a diverse form of adult education, offering courses aimed at compensating for previous school failures or the lack of educational attainment, providing vocational courses, and offering elite education in the cultural sphere. Some participants live at the school, others do not.

\section{Narratives on educational and occupational choice}

This article takes its starting point in the idea that individuals give meaning to their experiences and their existence, here and now, by telling stories, both to themselves and to others. In a way, we might say that individuals become who they are by the stories they tell, about themselves and their lives: individuals themselves reflect the stories they are (McAdams, 1993). Thus, an individual's meaning-making and storytelling is an important point of departure in understanding, for instance, their educational and occupational choices. In line with this argument, the article employs a narrative approach, whereby the narrative is seen as 'the primary form by which human experience is made meaningful' (Polkinghorne, 1988, p. 1). As Bamberg (2010, p. 77) says, the narratives that individuals tell themselves and others 'give "narrative form" to experience'.

They position characters in space and time and, in a very broad sense, give order to and make sense of what happened - or what is imagined to have happened. Thus, it can be argued, that narratives attempt to explain or normalize what has occurred; they lay out why things are the way they are or have become the way they are.

In line with this approach, we interviewed participants on two different courses at a folk high school located in a mid-sized city in Sweden in order to elicit narratives on educational and occupational choice. The two courses are a basic course (n14) and the theatre course (n10). The school was chosen due to its size, providing a range of courses with potential data access, as well as a site where access was granted. The interviews lasted between 30 and $60 \mathrm{~min}$. All interviews were recorded and then transcribed verbatim. The interviews focused on questions about what participants considered to be important regarding educational learning for their presumptive occupational futures, both inside and outside popular education. Among other things, the interviewees spoke about why they had taken up studies at the FHS and about their aspirations for the future.

Based on an initial qualitative thematic analysis of the narrative data, we have been able to identify five distinct trajectories among the participants interviewed, in terms of their main reasons for engaging in studies at FHS. Firstly, we identified what established each of these trajectories as emerging through interviewees' narratives. Secondly, we focused on how these trajectories were related to each other. 
We specifically focused on the significance ascribed to past and present experiences for participants' educational and occupational choice (cf. Polkinghorne, 1995). The five trajectories identified are: a desire to get away; a desire to get back on track; a desire for employment; a desire to change occupation; and a desire to realise one's dreams. In the following section, each of the five trajectories will be exemplified by narratives from two participants each. These, in total, ten stories have been selected as illustrative of the five trajectories identified. However, these trajectories are not mutually exclusive, but overlapping. Participants most often mention several motives for engaging in studies at FHS, and we have categorised them in the trajectory most dominant in their story.

\section{A desire to get away}

A central argument for why some participants have chosen to engage in studies on the basic course or the theatre course connects up with experiences of exclusion and/or a broken family. A desire to get away from social problems and the family emerges in these participants' narratives. As Belar, one of the participants on the basic course elaborates:

I didn't manage upper secondary school due to a bad home environment. I had a younger sister with ADHD, and my mother was single. It was a hard time for me and I thought that I couldn't stay there and continue my studies as I didn't do that well in upper secondary school. I felt really bad. I was often together with my mother taking care of my sister. So I thought that I had to get away from all of that. It was quite a long period. It continued for several years [...] So I thought: 'I have to save myself and stand on my own feet.' So I came here [to the FHS] to try to live alone and maybe manage my studies. I want to continue my studies at university, and thus have a future. Something like that. I don't really know what I want to become. I just want to have a good life. School is the most important thing. It's not hard to change one's life I think, but it's hard to find the motivation. My teacher and counsellor told me that FHS was a good idea. Although I needed a lot [to study many subjects]. So they told me that FHS would be a good way to get away and get my upper secondary school degree. (Belar, 19 years old, basic course)

Here, Belar tells us about her background and that she did not manage to complete upper secondary school due to a tough situation at home, not least the need to support her single mother and her sister with ADHD. She tells us that, when she grew up, she helped out with her sister a lot. Eventually it became too much. She decided that she needed to get away from home, away from the things that made her feel bad and away from the heavy duties laid on her regarding her sister. By getting away, she could take care of herself and her life. The basic course at the FHS made such choices possible. She dreams about a future of university studies. Belar tells us that she was supported by a counsellor and her teacher in upper secondary school, who told her about the FHS as an option, a place that could be good for her and where she could gain eligibility to apply for higher education. A move to the FHS also 
meant that she could focus more on school, or as she herself puts it: 'to stand on my own feet'.

Saga is registered on the theatre course, and her narrative has similarities to Belar's. For Saga, there is also a narrative of a broken home, which in her case eventually resulted in her being placed in a foster home. We here let Saga tell us a bit more about the trajectory that brought her to the FHS and her thoughts about the future:

I grew up in a broken home, in a nice area of the city, beautiful, where a lot of people with high incomes live. I grew up with my mother who is a nurse [...] I had my best friend, the kind of girl who always came to school dressed in a sailor dress and braids [...] We played together a lot from kindergarten up to the first years in school. Eventually, we came to a point where I was no longer welcome at her home because her father didn't like that my mother was a social democrat [...] My mother passed away when I was nine so I lived with my father who was a drug addict, and my friend's parents knew this, and thus they were even more reluctant to let her play with me [...] When I grew older, I was placed in a foster home in an area where the rich people live, a place where it's like, you should have the nicest care. I had a hard time fitting in there, because I didn't feel that I belonged.

It all started out with pills. I've tried everything, but it was mostly pills for a long time. Every now and then I tried something different, but never any longer periods with heroin. And then, during secondary school, I met this fantastic woman, a recreational leader. She took care of me. At first, I was like: 'Don't come near me', 'I don't want to', 'You're stupid', and 'You're like that'. But she never gave in. She had decided that she would help me. So I managed to get my grades and get into the child recreation programme at upper secondary school. I then had a period when I didn't do drugs and I told myself: 'No, I have to get things in order'. My studies went ok, but I was lazy. I was never really a motivated student. And then I had a short relapse and life didn't turn out so well for me. But eventually, I decided to become a youth recreational leader.

I got a bit involved in acting as a child, but nothing special. My dad is a musician, and my sister has always been involved in acting. Both she and I went to a music class at school. And then I started the theatre class here [at the FHS] and I told myself: 'This is fun, this is what I want to do'. I've been in my sister's shadow a lot. She was so gifted at singing and acting, so I thought no, but the theatre course, I'll apply for that. Since I was admitted, a new world has opened up [...] Now, I'm more like, I no longer want to work in a youth recreational centre, I will put my efforts here, into the things you dream of, dreams many people never follow. I won't be afraid [...] It's a bit like therapy. That's the wrong word, but you always have to express yourself. You can express yourself by dancing and you can express your emotions. And the things you need to express, they're accepted. You can do whatever you want. Such freedom, it's like, really cool. You don't have to take any responsibility for it [the emotions expressed] [...] In ten years, I hope to be able to do anything I want, 
to be as creative as possible, no matter if it's about doing theatre, plays, or if I'll work with movies. Whatever I do, it will be something creative. (Saga, 22 years old, theatre course)

Like Belar, Saga comes from a broken home, where initially she was living with her mother, who was a nurse. However, when her mother passed away, Saga moved to live with her father who was a musician and drug addict. In the end, she was placed in a foster home. When she lived with her mother, as well as when she was in the foster home, she was living in what she describes as a 'nice area'. But she never felt that she really belonged there. The feeling of being different emerged in several ways, not least based on her father's drug addiction, but also on her mother's political beliefs, which were not acceptable to her best friend's father. The feeling of being different also emerges through the experience of exclusion when friends were talking about nice cars and such things. In the end, Saga started to do drugs of different sorts, but mostly pills.

Luckily, there was a youth recreational leader who took it upon herself to support Saga in taking control of her own life. Through such support, Saga managed, at least temporarily, to break free of the drugs and to enter upper secondary school. However, she soon fell back into doing drugs and thus she quit school. Eventually, she decided once again to become free of the drugs, and then she started an education course at an FHS in order to become a youth recreational leader. This choice was made possible by her positive experience of the recreational leader who had helped her previously, as well as on her own experiences of exclusion in the past (see Fejes \& Dahlstedt, 2018 for further descriptions of becoming a youth recreational leader). However, Saga soon felt that this occupational choice was not for her, and she entered the theatre course instead, a course she finds very satisfying. She tells us that she has always been in the shadow of her sister, a sister who was good at singing and acting. But now, since Saga started the theatre course, she has discovered that acting and theatre are something she is good at. She describes her studies as a therapeutic process, which gives her space to express her feelings through other means than speech, not least through dancing. She experiences great freedom in such forms of expression. She dreams about the future as a life that will move on in a positive direction. From having a dream of becoming a youth recreational leader, she now dreams about working in theatre or the movies, something creative.

\section{A desire to get back on track}

Another trajectory leading into studies at FHS concerns a determination to recover from a shorter or longer period of illness, combined with experiences of educational failure and/or poor working conditions. The choice to enter FHS is here made based on the potential contribution of the educational programme to the individual's rehabilitation process. Elin, one of the participants on the basic course, tells us:

The reason why I'm here is because I've been on sick leave for a while. Previously, I studied at MAE, due to dropping out of upper secondary school. However, my studies at MAE became too much. I studied so many subjects, 
full-time studies, and it simply became too much. And maybe I wasn't that motivated, and I wasn't feeling well during that period, so I quit. I didn't have the energy to complete an upper secondary school degree. Instead, I've been on sick leave, I've had temporary employment and such. And then, I was offered the possibility when I was registered with the employment office, to do a course here, and so I did. I really enjoyed this school, so I stayed. I don't know. I'm interested in architecture and such things, so I don't know. But not an architect. There are shorter courses that might make it possible to work with architecture. I'll check that out a bit better. I like to be creative and create stuff, and I like houses and such [...] So something in those areas, that's what I've been thinking about, but we'll see. (Elin, 34 years old, basic course)

Elin tells us that she did not complete her upper secondary school education, and she chose to complete these at MAE. Full-time studies at MAE became too much, so she quit. Instead, she experienced several periods of sick leave in combination with temporary employment. At the employment office, she was supported in applying for a course at the folk high school, which she did. She is now studying on the basic course, which she is satisfied with. Studying at folk high school suits her well, she tells us. By participating in these studies, she has become more motivated and now Elin dreams about a future where she can work with architecture in some way. She wants to work with something creative.

For Nanny, the trajectory towards entering FHS studies was somewhat different from Elin's. Nanny had a job she was satisfied with. As a youth recreational leader, she was working at a youth recreational centre. While working there, she was also responsible for study circles directed towards the theatre, organised by one study association. She is still working part time, at the same time as studying at the FHS. Nanny tells us that, previously, when she was working at the study association, she was burnt out and ended up on a long period of sick leave:

I'm a youth recreational leader, and directly after finishing my education I was employed at a youth recreational centre. After a while, I also became responsible for study circles in theatre at one of the study associations in this county. [...] I work extra now, but not as much as before. I work at a home for female drug addicts [...] The county is big, and I worked alone and was burnt out really badly. I was treated badly, so I was on sick leave for a long period of time. I became really ill, mostly physical. My body shut down, so I had to go for a lot of medical examinations, so it was a physical sickness. But also a depression. [...] Before I came here [to the FHS], I was really fed up with theatre. I didn't want anything to do with it. But I applied, for egoistic reasons, for my own sake, as a way to try to become better, physically as well as mentally. It would be a way to challenge myself, to study economics and such things, which I don't really like [...] If I could dream, I will have financial stability. However boring it may sound, it would mean so much, as I would then be able to do anything I wanted, maybe engage more as a volunteer, I could work as many hours I liked. (Nanny, 32 years old, theatre course) 
Even though Nanny did not previously think that theatre was the occupation she would have in the future, she chose to apply for the theatre course, as part of her rehabilitation plan. Her choice of education was based on, as she tells us, 'egoistic reasons, for my own sake, in order for me to feel good'. At the same time, the choice was a bit of a challenge, as she would then have to study subjects that she really did not like. When she talks about her dreams for the future, she sees a future of financial stability, thus making it possible for her to engage in issues on a voluntary basis, to the extent that she wishes and that suits her.

\section{A desire for employment}

Some participants told us that they ended up at the FHS in order to become employable, i.e. to get a job. However, these participants are not always clear about what specific occupation they are aiming for. The desire for employment as the main reason for studies at the FHS is mostly accentuated by participants on the basic course. Education here becomes a means to gain qualifications at the same time as it provides time during which one can think about what one would like to do in the future, after completing one's studies. For instance, Teo tells us that he has never known what he wants to become in terms of occupation. After secondary school, he entered the hotel and restaurant programme at upper secondary school, as his sister was already working in that particular area. He was working in an hourly based job in order to get his finances together. But it was hard. Before deciding to apply for the FHS, he had no money because he was working too little. He describes his working conditions as highly precarious, involving him moving around to get hourly employment, which in the end was not worth it, as it just did not generate sufficient income. He then started to study in circles organised by one of the study associations. When he told the circle leader about his ambition to apply for FHS, he was encouraged to do so. For Teo, the choice of entering the basic course at FHS was a big step forward in life.

I've never known what I want to get educated for, so this hotel and restaurant stuff was something I just went into due to the stress after ninth grade: 'Well, what am I supposed to do now?' And then my sister went into the hotel and restaurant programme, and she said that it's fun, and so on. Food is good, it's good to eat, kind of [...] I was employed by the hour, it was mostly because, you know, you have to do something to get the finances running. [...] Before I was enrolled in the FHS, I had no money, because I rarely worked. I only got to work the worst hours, when you have to go to a lot of different places, all day, and just do small jobs. But I told myself to stop doing that, because it was just not worth the trip on the bicycle out into the countryside just for two hours, to work. [...] So, before I started here, I didn't do very much. I went to a study association.[...] When I told them I was thinking about studying and was considering FHS, they really pushed me to start studying. Because it's very easy when you just stay at home, to get a little lazy and maybe a little shy of people and you don't have the energy... Yes, and then there was this school. (Teo, 22 years old, basic course) 
In Joseph's case as well, the desire for employment stands out as the most important motive for entering the FHS.

Joseph That's a good question. I don't even know if I know that myself. I happened to end up here. No, but I was engaged in studies at MAE previously. Since then, I've been working for a few years, and then I felt that I would like to start studying again. And then I chose between MAE and FHS. The girl from the City recommended FHS, so just one week before the school started, I applied. I was enrolled, so here I am

Researcher How long will you study here?

Joseph I really don't know. Perhaps one year or so, or maybe two. I really don't know. I just come here, study and then I hope that it will be over as soon as possible. [...]

Researcher How would you like your life to be in like ten years?

Joseph I don't know. Hopefully, I'll have finished school. Actually, I think I'll be working with something that I really enjoy

Researcher Is there anything you know you would like to work with, right now?

Joseph No, well, I'll have to figure that out, think of something that's interesting. Something that I'll enjoy doing for a long time, too. So I'll not get tired of it after five or ten years

Researcher Do you think this is how it will be?

Joseph I don't know. This is a difficult question. You have to wish that it will happen and really strive for it, but then it may happen that there isn't so much work available, and then you'll perhaps need to find something else to do. Anyway, I hope that there will be work available in that business. I hope. (Joseph, 22 years old, basic course)

Joseph tells us that he ended up at the FHS more or less by accident. He had experience of a few years of studies in MAE, and some work experience. After a few years in working life, he felt that it was time to study again, and the choice was between MAE and the FHS. When a person recommended the FHS, he made his choice, and ended up on the basic course. He hopes to finish his studies as soon as possible in order to find a job he enjoys. However, he does not yet know what that occupation would be. He describes his studies as a way to find a new job as well as finding time to find out what job he would like to have in the future. However, no matter what, the occupation does at least have to be something interesting, and something he will not easily get tired of.

\section{A desire to change occupation}

A desire to change occupation is yet another reason for engaging in studies at FHS. As with the desire to find employment, the desire to change occupation is more common in interviewees on the basic course, as compared to participants on the theatre course. For participants on the basic course, a change in occupation is not primarily related to a process of rehabilitation, but rather as a way to gain new energy in 
working life. As Emma, a participant on the basic course who previously worked as a hairdresser, tells us:

I just have to say: This is so much fun. At first, I just wanted to have another job and then I thought: then I have to go to upper secondary school to get a different education, as fast and soon as possible. So I thought, I'll just complete these two years, so I can apply for the next school. But now, these two years are almost over. [...] I've thought a lot about why it turned out the way it did, but I think I felt that I did what I did, that I've been doing it for so long and so much that it was just no longer fun. So I wanted to get to know whether I could do something more. And I think it was this ability to think that I really missed. When you work as a hairdresser, you meet the same people. You know, you talk about cake recipes, traditions. Some people you get to have deeper conversations with, but otherwise it's very, I felt that I was very tired of this superficial stuff. (Emma, 39 years old, basic course)

Here, the choice of entering the FHS is related to Emma's desire to find a different occupation. Such a determination to change turned her path towards the FHS. She expresses a feeling of having worked too long as a hairdresser, and thus it was no longer any fun. A feeling of wanting to do something more in life grew stronger, and not least, as she tells us, a desire to stimulate 'the ability to think'. She describes being a hairdresser as too repetitive and not very intellectually stimulating, not least as it is usually the same people coming back, and the conversations with customers usually end up concerning everyday issues such as cake recipes.

Another participant on the basis course, Ehan, also felt that it was time to find a new occupation. He had previously been in construction work, painting houses, drilling and renovation. This occupation was varied, it was good pay, but toilsome. Now that he is enter his mid $20 \mathrm{~s}$, he wishes to find a new occupation, and thus he is studying at the FHS.

I studied social science/economics at upper secondary school, but then I started working and I enjoyed building things. Then I had this contact, so I started working, painting roof tiles, and then I got into concrete and also renovation [...] However, I won't be able to do this forever. It's very demanding, physically. I got up at quarter past five and came home at seven every day, so you don't have time to do much more. The money's good. I don't want to be paid less. Perhaps you get a bit greedy, but when you're young you have to seize the opportunity and work as much as possible. I'm going to study here and then maybe study to become a teacher or to work in systems science, or I'll see. I'm so bad at maths, so probably I won't be able to go into systems science, but maybe something else, a teacher of philosophy, psychology or something like that, sports. (Ehan, 23 years old, basic course)

Long working hours and strenuous work are here contrasted with a good income. Thus, a desire to change occupation has shifted Ehan's trajectory, from his previous occupation into studying on the basic course. However, due to the relatively good income in his previous occupation, he does not see himself taking just any job. He 
has become used to a certain standard of living and thus he does not want to have a lower wage than was previously the case. Concerning the choice of occupation, Ehan has several ideas. Which one he will finally end up in is still undecided. But one thing is certain, the way forward starts with further studies, first on the basic course at the FHS and then onwards, to higher education, and perhaps then becoming a teacher or working in systems science.

\section{A desire to realise one's dreams}

Several of the participants describe their studies at the FHS as part of realising their dreams. However, this narrative is only visible in interviews with participants on the theatre course. As Joar tells us, he is attending the theatre course as part of his personal development; in this case, as a way of discovering what he would find most interesting to do in life.

I went to a music school, and after that I wanted more of what they taught and then I came here [...] Both in terms of personal development and emotionally, we get a broader repertoire of expressions or that kind of thing. You get to know what you really enjoy doing [...] I think it's a goal to be able to choose what you want to do, to say no to things you don't want to do, so you don't have to sell out, but that's quite difficult [...] I think that, say if you don't get a job in three years, but when you're into the fourth year, you just need to be diligent and keep on struggling. You should not give up, I believe in karma. (Joar, 22 years old, theatre course)

Joar tells us that a goal for everyone should be to have the opportunity to say no to anything they do not like. In other words, the goal should be self-realisation, to follow one's dreams in life. At the same time, he is conscious of the challenges of getting a job in the area he is educating himself for. Despite this, he expresses a strong belief in his ability to realise his dreams, not least based on hard and tenacious work.

Ane, another participant on the theatre programme, tells us that she does not really know if the course will lead to a job.

It's all about Bengt and Sigrid [both teachers on the theatre course], that I've been working with them. They told me they would start a course and then my first question was: 'How do I apply?' [...] Actually, I'm trying not to think so much about it, because then I get kind of panicky. I hope I'll be able to create a job that I think is fun. I want to have fun... I don't know if we live more than once, but I'm here now, so I need to try to get the best out of it, somehow. I had a long and difficult time when I was living in Denmark, so because of that, it's really nice to find things that are playful, fun and bright, just to have fun, kind of. I think that's extremely important. [...] In ten years, then I would like to have a little cabin, some place and a wonderful husband and a couple of kids who are great fun. And then a cat and a dog. And then I would work everywhere, as much as I want, take the kids maybe... work internationally, in different places and with different projects, and get variety all the time, do different things, and not do the cleaning, sort of. [...] But I still think it's impor- 
tant to have a base, because I don't like not having roots somewhere, kind of. I want to feel at home, and then you can run around. (Ane, 29 years old, theatre course)

As expressed here, Ane chose to enter the programme primarily due to the teachers, as they are people she really wants to work with in the future. She tells us that she has had a tough period abroad, living in Denmark, and thus she now feels that she has to engage in studies which are fun. For her, the educational choice is a way to break free from a bad situation. She dreams about a future with a family, and an occupation where she has the opportunity to travel and work internationally. In such a working life, she imagines opportunities to work with anything she likes, and as much as she likes. She wants to work on different projects, in order to get variety, and at the same time, backing up this working life of travelling, she wants to have a stable place, a place to call home.

\section{Concluding discussion}

In this article, we have highlighted both similarities and differences between educational and occupational trajectories among participants on the basic course and the theatre course at an FHS in Sweden. We have identified five different trajectories across the interviews. On both courses, there are participants who have entered studies at the FHS as a way to get away from broken homes, as a new start in life, or as a way to overcome previous educational failures in order to become eligible to enter higher education. We have also been able to identify examples from both courses, of participants who view their studies as a way of returning to work after a shorter or longer period of sick leave. In these cases, studying at FHS becomes part of a rehabilitation process, on the path towards new goals in life. However, we have also identified three trajectories unique to one or other of the two courses. For some of the participants on the basic course, studying at the FHS is a way to become employable. However, many of these participants are unclear about exactly what occupation they are interested in. In most of these cases, studying at the FHS becomes a way to get away from a precarious labour market. The same goes for the trajectory focused on finding a new occupation. For these participants on the basic course, FHS is a way to find a new occupation. Such result resembles the result provided by Dahlstedt et al. (2018). They argue that many of those with a working class background entering municipal adult education in Sweden, do so in order to leave a precarious labour market, and to find ways to find new employment or to become eligible for entering certain programs in higher education, such as the program for social work or teacher training.

The final trajectory only emerges in the interviews with participants from the theatre course. Here, FHS becomes a means to realise one's dreams in life. Such a trajectory could be cast in the light of Nylander's (2014) study, illustrating how, as well as providing general education for the broader layers of the population, the FHS also provides elite courses attracting a different group of participants. Or rather, the FHS becomes a site where the social stratification of society at large becomes visible, 
based on who is there, and what kinds of courses they attend. those attending cultural courses at folk high schools, and especially courses in theatre, are most likely to come from a higher class background (Fürst et al. 2018). We can also connect back to Rubenson (1975) who illustrated that those, in the 1970s, with higher level of education, where more likely to choose adult education as a way for personal development as compared to those with lower levels of education.

In sum, our study illustrates that participants on the basic course provide motives and ideals about work that to a large extent relate to working-class ideals, while participants on the theatre course, to a larger extent, describe motives that relate to middle-class ideals (see e.g. Reay, David \& Ball, 2005; Dahlstedt et al., 2018). This does indeed have consequences, because education for those who adhere to working-class ideals, i.e. a desire to gain employment, to rehabilitate or re-school oneself towards a specific occupation, becomes, to a large extent, a means to adapt to current norms in society and to fulfil one's duties by working hard and thus contributing to society.

Even though the empirical material analysed in this article is limited to quite a small number of participants, enrolled on two different courses, in one specific FHS in Sweden, we can nevertheless identify tendencies of how trajectories lead into studies at FHS, and how dreams about the future are given meaning by specific experiences, and are thus highly influenced by the particular background of the participants. The question one might pose, given these results, is: what dreams are possible, for whom, and who can realise such dreams? This in turn actualises questions concerning the very role of the FHS in society, and its ability to function as a collective power for social change and for making dreams of a different social order come true.

Open Access This article is distributed under the terms of the Creative Commons Attribution 4.0 International License (http://creativecommons.org/licenses/by/4.0/), which permits unrestricted use, distribution, and reproduction in any medium, provided you give appropriate credit to the original author(s) and the source, provide a link to the Creative Commons license, and indicate if changes were made.

\section{References}

Assarsson, L., \& Sipos-Zackrisson, K. (2005). Iscensättande av identiteter $i$ vuxenstudier [Staging identities in adult education]. Linköping, Sweden: Linköping University.

Assarsson, L. \& Sipos-Zackrisson, K. (2006). Att delta i vuxenstudier [To participate in adult education]. In S. Larsson \& L-E. Olsson (Eds.), Om vuxnas studier [About the education of adults] (pp. 93-108). Lund, Sweden: Studentlitteratur.

Bamberg, M. (2010). Narrative Analysis. In H. Cooper (Ed.), APA handbook of research methods in psychology (pp. 77-94). Washington, DC: APA Press.

Billett, S., Newton, J., \& Ockerby, C. H. (2010). Socio-personal premises for selecting and securing an occupation as vocation. Studies in the Education of Adults, 42(1), 47-62. https://doi. org/10.1080/02660830.2010.11661588.

Bloomer, M., \& Hodkinson, P. (2000). Learning Careers: Continuity and change in young people's dispositions to learning. British Educational Research Journal, 26(5), 583-597. https://doi. org/10.1080/01411920020007805.

Brown, S. G., \& Barbosa, G. (2001). Nothing is going to stop me now: Obstacles perceived by lowincome women as they become self-sufficient. Public Health Nursing, 18(5), 364-372. https://doi. org/10.1046/j.1525-1446.2001.00364.x. 
Dahlstedt, M., Sandberg, F., Fejes, A., \& Olson, M. (2018). Dissonant futures: Occupational trajectories, gender and class in contemporary municipal adult education in Sweden. Journal of Education and Work, 31(1), 16-27. https://doi.org/10.1080/13639080.2017.1400661.

Edquist, S. (2009). En folklig historia [A Popuar History]. Umeå, Sweden: Boréa.

Evans, K. (2002). Taking control of their lives? Agency in young adult transitions in England and the New Germany. Journal of Youth Studies, 5(3), 245-269. https://doi.org/10.1080/1367626022 000005965.

Fejes, A. \& Dahlstedt, M. (2018). Becoming the role model: youth recreational leaders, occupational choice and a will to include. Discourse: Studies in the Cultural Politics of Education, 39(6), 901-912. https://doi.org/10.1080/01596306.2017.1308917

Fejes, A., Dahlstedt, M., Olson, M., \& Sandberg, F. (2018). Adult education and the formation of citizens: A critical interrogation. London: Routledge.

Fejes, A., \& Köpsén, S. (2014). Vocational teacher's identity formation through boundary crossing. Journal of Education and Work, 27(3), 265-283. https://doi.org/10.1080/13639080.2012.742181.

Fejes, A., \& Nicoll, K. (2010). A Vocational Calling. Pedagogy, Culture \& Society, 18(3), 353-370. https://doi.org/10.1080/14681366.2010.504646.

Fürst, H., Levelius, S., \& Nylander, E. (2018). Kulturell bildning i folkhögskolans regi: Deltagare och lärare på estetiska profilkurser [Cultural bildung organised by folk high schools: Participants and teachers in aesthetic coures]. Stockholm, Sweden: Folkbildningsrådet.

Gottfredson, L. S., \& Lapan, R. T. (1997). Assessing gender-based circumscription of occupational aspirations. Journal of Career Assessment, 5(4), 419-441. https://doi.org/10.1177/1069072797 00500404.

Gustavsson, B. (2013). The idea of democratic building: Its transformations in time and space. In A.-M. Laginder, H. Nordvall, \& J. Crowther (Eds.), Popular education, power and democracy: Swedish experiences and contributions (pp. 35-49). Leicester, UK: NIACE.

Hodkinson, P., \& Sparkes, A. W. (1997). Careership: A sociological theory of career decision making. British Journal of Sociology of Education, 18(1), 29-44. https://doi.org/10.1080/0142569970 180102.

Kane, L. (2013). Comparing 'Popular' and 'State' Education in Latin America and Europe. European Journal for Research on the Education and Learning of Adults, 4(1), 81-96. https://doi. org/10.3384/rela.2000-7426.rela0085.

Larsson, S. (2013). Folk high schools as educational avant-gardes in Sweden. In A.-M. Laginder, H. Nordvall, \& J. Crowther (Eds.), Popular education, power and democracy: Swedish experiences and contributions (pp. 72-96). Leicester, UK: NIACE.

Lidström, L. (2010). Mödan att finna och nå sina karriärmål [The Efforts of Finding and Achieving One's Career Goals]. In L. Lundahl (Ed.), Att bana vägen mot framtiden [Building the Future] (pp. 103-126). Lund, Sweden: Studentlitteratur.

Mau, W. C., \& Bikos, H. (2000). Educational and vocational aspirations of minority and female students: A longitudinal study. Journal of Counselling \& Development, 78, 186-194. https://doi. org/10.1002/j.1556-6676.2000.tb02577.x.

McAdams, D. P. (1993). The stories we live by: Personal myths and the making of the self. New York: Guilford Press.

Micheletti, M. (1995). Civil society and state relations in Sweden. Aldershot: Avebury.

Nylander, E. (2014). Skolning i jazz: Värde, selektion och studiekarriär vid folkhögskolors musiklinjer [Schooling in Jazz: Value, Selection and Study Careers in Music Courses at Folk High Schools]. Linköping, Sweden: Linköping University.

Polkinghorne, D. E. (1988). Narrative knowledge and the human sciences. Albany: State University of New York Press.

Premfors, R. (2000). Den starka demokratin [The Strong Democracy]. Stockholm, Sweden: Atlas.

Reay, D. (1995). 'They Employ Cleaners to Do That': Habitus in the primary classroom. British Journal of Sociology of Education, 16(3), 353-371. https://doi.org/10.1080/0142569950160305.

Reay, D., David, M. E., \& Ball, S. (2005). Degrees of choice: Social class, race and gender in higher education. Stoke-on-Trent, UK: Trentham.

Rojewski, J. W., \& Yang, B. (1997). Longitudinal analysis of select influences on adolescents' occupational aspirations. Journal of Vocational Behavior, 51(3), 375-410. https://doi.org/10.1006/ jube.1996.1561. 
Rubenson, K. (1975). Rekrytering till vuxenutbildning - en studie av kortutbildade yngre män [Recruitment to adult education: A study of younger men with limited educational background]. Göteborg, Sweden: Göteborgs Universitet.

Sellers, N., Satcher, J., \& Comas, R. (1999). Children's occupational aspirations. Professional School Counselling, 2(4), 314-317.

Simpson, R. (2005). Men in non-traditional occupations: Career entry, career orientation and experience of role strain. Gender, Work and Organization, 12(4), 363-380. https://doi.org/10.111 1/j.1468-0432.2005.00278.x.

Swedish Council for Adult Education. (2018). Årsredovisning 2017 [Annual Report 2017]. Stockholm: Swedish Council for Adult Education.

Publisher's Note Springer Nature remains neutral with regard to jurisdictional claims in published maps and institutional affiliations.

\section{Affiliations}

\section{Andreas Fejes $^{1}\left(\mathbb{0} \cdot\right.$ Magnus Dahlstedt $^{2}$}

$\triangle$ Andreas Fejes

andreas.fejes@liu.se

Magnus Dahlstedt

magnus.dahlstedt@liu.se

1 Department of Behavioural Sciences and Learning, Linköping University, 58183 Linköping, Sweden

2 Department of Social and Welfare Studies, Linköping University, 60184 Norrköping, Sweden 